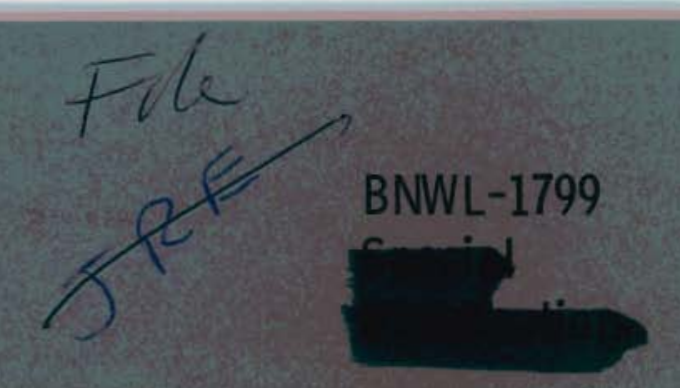

\title{
PACIFIC NORTHWEST LABORATORY MONTHLY ACTIVITIES REPORT OCTOBER 1973
}

Division of Production and Materials Management and Hanford Plant Assistance Programs

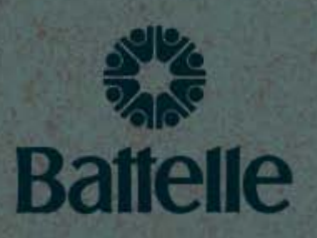

Pacific Northwest Laboratories

Richland, Washington 99352

NOVEMBER 1973

Prepared for the U.S. Atomic Energy

Commission under Contract AT(45-1):1830 


\title{
PATENT STATUS
}

This document copy, since it is transmitted in advance of patent clearances, is made available in confidence solely for use in performance of work under contracts with the U.S. Atomic Energy Commission. This document is not to be published nor its contents otherwise disseminated or used for purposes other than specified above before patent approval for such release or use has been secured, upon request, from the Chief, Chicago Patent Group, U.S. Atomic Energy Commission, 9800 So. Cass Avenue, Argonne, Illinois, 60439.

\section{PRELIMINARY REPORT}

This report contains information of a preliminary nature prepared in the course of work under Atomic Energy Commission Contract AT(45-1)-1830. This information is subject to correction or modification upon the collection and evaluation of additional data.

NOTICE

The report was prepared as an account of work sponsored by the United States Government. Neither the United States nor the United States Atomic Energy Commission, nor any of their employees, nor any of their contractors, subcontractors, or their employees, makes any warranty, express or implied, or assumes any legal liability or responsibility for the accuracy, completeness or usefulness of any information, apparatus, product or process disclosed, or represents that its use would not infringe privately owned rights.

\author{
PACIFIC NORTHWEST LABORATORY \\ operated by \\ BATTELLE \\ for the \\ U.S. ATOMIC ENERGY COMMISSION \\ Under Contract AT(45-1)-1830
}




\title{
33679000623092
}

BNWL-1799

Special Distribution

\author{
PACIFIC NORTHWEST LABORATORY \\ MONTHLY ACTIVITIES REPORT
}

OCTOBER 1973

Division of Production and Materials Management

and

Hanford Plant Assistance

Programs

by the

Staff of Battelle-Northwest

E. L. Alpen, Director

November 1973

BATTELLE

PACIFIC NORTHWEST LABORATORIES

RICHLAND, WASHINGTON 99352 


\section{TABLE OF CONTENTS}

Page

Assistance to Atlantic Richfield Hanford Company - Sumary . . . . . . 3 Assistance to Atlantic Richfield Hanford Company . . . . . . . . . . 6

Technical Assistance to the Hanford Plant - Summary . . . . . . . . 17

Technical Assistance to the Hanford Plant . . . . . . . . . 18 


\section{PACIFIC NORTHWEST LABORATORY \\ MONTHLY ACTIVITIES REPORT \\ DIVISION OF PRODUCTION AND MATERIALS MANAGEMENT \\ AND HANFORD PLANT ASSISTANCE PROGRAMS \\ ASSISTANCE TO ATLANTIC RICHFIELD HANFORD COMPANY \\ $\underline{\text { Summary }}$}

Process Development, Research and Development Department

Plutonium Scrap Processing Development

In tests of a $\mathrm{NaOH}-\mathrm{Na}_{2} \mathrm{O}_{2}$ fusion process for recovering Pu from incinerator ashes, more than 95 percent of the Pu present was soluble in $\mathrm{HNO}_{3}$ after fusion of incinerator ashes in an equal-weight $\mathrm{NaOH}-\mathrm{Na}_{2} \mathrm{O}_{2}$ mixture at an ash to melt weight ratio of 0.286 .

Process Technology, Operations Support Engineering Department Waste Concentration and Encapsulation Support

Instrumentation to measure percent solids in the 242 -waste concentrator was designed, constructed, tested and delivered to the plant.

Process Technology, Research and Development Department

Plutonium Trench Soil Characteristics

Plutonium trench chemistry studies indicate that plutonium will extract from an aqueous phase containing Pu Polymer to a TBP-diluent phase if fluoride ion is added to the aqueous phase.

Soil from near the 216-2-9 trench and plutonium polymer were equilibrated. The soil was dried, mounted and polished and will be examined for diagnostic differences between this and other plutonium forms on the 216-Z-9 trench soil.

Measurement of a group of soil chemical parameters in an initial core from the 216-Z-9 covered trench was completed.

Tank Farm Support

Particle densities of $\mathrm{T}$ Tank Farm soils were found to be 2.8 to 2.9 , higher than expected. 
Simultaneous measurement of hydraulic conductivity and moisture content are possible now with a new laboratory technique.

Work was continued to measure soil chemical and sorption parameters for a transport model determination of the movement of radionuclides from a high-level waste tank leak.

Prevention of Accidental Releases

- Surficial Contamination

The concentration of $\mathrm{Cs}-137$ in materials collected from ten random plots in the B-C Crib Area, Zone 2, ranged from 0.53 to $5.9 \mu \mathrm{Ci} / \mathrm{m}^{2}$ with an average value of $13.4 \mu \mathrm{Ci} / \mathrm{m}^{2}$. Approximately 90 percent of the activity was found in the soil.

In a study to determine the manner in which a small quantity of a finely divided solid of known size distribution would be distributed among size fractions of soil after thorough mixing, particles of $\mathrm{UO}_{2}$ with an aerodynamic equivalent mean diameter of about $1 \mathrm{\mu m}$ were found preferentially with the finer fractions, but in a proportion that suggested the $\mathrm{UO}_{2}$ was distributed more or less proportionately to soil particle surface area.

When a coarse fraction of soil from the B-C Crib Area was contacted with water, greater than 99 percent of the Cs -137 present remained associated with particulate material - 47.3 percent with the washed soil, 49.5 percent with fine particles caught on filters and 2 percent with organic material.

Additional resuspension experiments, one at $\mathrm{U}$ Area and one at $\mathrm{B}-\mathrm{C}$ Area, were completed. Analytical results are awaited. Radiochemical results made available for earlier experiments showed detectable airborne quantities of $\mathrm{Cs}-137, \mathrm{Be}-7, \mathrm{Ru}-103$, and $\mathrm{Rh}-106$.

Windfield derived trajectories were compared with constant volume balloon trajectories during the two-week experiment in April. Aircraft tracking of a constant volume balloon was shown to be feasible in examining regional scale transport.

Vertical wind observed on the Hanford Meteorological tower suggests opposing drainage flow can occur during periods of strong thermal stability. 
- Groundwater Management Studies

Data from five bi-weekly water table measurements are being entered into the computer to develop the temporal rate of change map for the groundwater system.

Numerical roundoff error of iterative processes is being studied to estimate the growth of error as a function of simulation period. This will help develop optimum convergence criteria for the groundwater models.

Preparations are underway for a dye tracer study on the 216-U-10 pond.

- Biological Transport Studies

A marked increase in pond usage by waterfowl as we11 as sma11 songbirds was noted in continued waterfowl census studies.

Goldfish enclosed over pond sediments and aquatic plants of relatively low radioactivity levels stabilized in Cs-137 content in about two months while those enclosed over sediments and aquatic plants of relatively high radioactivity levels had not stabilized in Cs-137 content at three months.

Studies on the uptake of actinide elements by plants growing on contaminated soil show that $\mathrm{Np}, \mathrm{Pu}, \mathrm{Am}$ and $\mathrm{Cm}$ are translocated downward much more readily than upward in the plant body. 
ASSISTANCE TO ATLANTIC RICHFIELD HANFORD COMPANY

Process Development - Operations Support Engineering Department

Plutonium Scrap Processing Development

Recovery of Plutonium from Incinerator Ashes

(J. A. Partridge, Chemical Development Section and

E. J. Wheelwright, Applied Chemistry Section)

Further tests were made of a process for recovering plutonium from incinerator ashes which involves fusion of the ashes with an equal weight mixture of $\mathrm{NaOH}$ and $\mathrm{Na}_{2} \mathrm{O}_{2}$ followed by dissolution of the cooled mixture in $\mathrm{HNO}_{3}$. The current series of tests investigated the effect of the weight ratio of ashes to the $\mathrm{NaOH}-\mathrm{Na}_{2} \mathrm{O}_{2}$ mixture. Ratios in the range of 0.215 to 0.428 were used. In prior tests reported for this study a weight ratio of 0.143 was used. Of the $\mathrm{Pu}$ initially present in the ashes, 91 and 98 percent was soluble in $\mathrm{HNO}_{3}$ after the fusion in two tests at an ash to $\mathrm{NaOH}-\mathrm{Na}_{2} \mathrm{O}_{2}$ ratio of 0.215. Similarly 95 and 97 percent was soluble in two tests at a ratio of 0.286 and 78 percent was soluble in one test at a ratio of 0.428 .

Apparently the incineration ashes contain some carbonaceous material. Some burning and flame production on the surface of the melt was observed in runs at ashes to $\mathrm{NaOH}-\mathrm{Na}_{2} \mathrm{O}_{2}$ weight ratios of 0.215 and 0.286 . The burning was more severe at the highest ratio tested, 0.428 , and produced popping sounds and spewing of the melt-ash mixture from the opening in the top of the container.

Process Technology - Operations Support Engineering Department

$\underline{\text { Waste Concentration and Encapsulation Support }}$

Instrumentation Development

(O. H. Koski, Chemical Development Section)

Effort during this report period was on documentation of previous development items which are presently in plant service and on the design, construction, testing and delivery of a system for solids analysis in the 242-S concentrator. 
Two reports which describe work which resulted in insta1led plant instrumentation have been written and are being cleared for issue. One, BNWL-B-302, is entitled, The Application of U1trasonics to Chemical Process Instrumentation, and the other, BNWL-B-271, is The Plusetronic Electrodeless Conductivity Instrument Reference Manual.

The instrument for measurement of solids content in the 242-S concentrator consisted of a conventional electrode type conductivity cell constructed in a 3 -inch pipe designed to be inserted in the 28 -inch process 1ine. Auxiliary equipment included the connector block, associated in-cell cabling and flexible fumeproof electrical jumper.

The presence of solids in the solution is indicated by a proportionate lowering of the conductivity. The temperature coefficient of conductivity of simulated concentrator solution was found to be more than twice that of nitric acid solutions and was higher for an electrodeless cell than for a conventional electrode cel1. The temperature coefficient remained constant despite the presence of solids during the test period but changed during overnight standing indicating that the solution is meta-stable with relatively little solids dissolving or precipitating during the test.

\section{Process Technology - Research and Development Department}

\section{Plutonium Trench Soil Characteristics}

Plutonium Trench Chemistry and Mineralogy

(J. L. Swanson, Chemical Development Section and

L. L. Ames, Land Resources Systems Section)

The behavior of plutonium polymer is being examined under conditions thought to be more typical of those under which the plutonium was charged to the 216-z-9 covered trench. Polymer formation was found (spectrophotometrically) to be quite rapid at pH 2 in either dilute $\mathrm{HNO}_{3}$ or in a high-salt solution typical of those charged to the trench $\left[2.4 \mathrm{M} \mathrm{NaNO}_{3}+0.6 \mathrm{M} \mathrm{Al}_{3}\left(\mathrm{NO}_{3}\right)_{3}\right.$ $\left.+0.3 \mathrm{M} \mathrm{Mg}\left(\mathrm{NO}_{3}\right)_{2}+0.2 \mathrm{M} \mathrm{NaF}\right]$. The polymer thus formed was readily sorbed by soil even in the presence of the high concentrations of salts; apparent $K_{D}$ values of several hundred were obtained at low Pu concentrations after only a 5 -min contact (the values tended to increase with time). At higher Pu concentrations, the concentration of sorbed Pu tended to level off at a value 
of about $1 \mathrm{mg}$ Pu/g soil. Removal of the laboratory-sorbed polymer by acid leach solutions occurred more readily than did removal of the $P u$ from the 216-Z-9 trench soil samples; possible effects of aging are under investigation.

Plutonium polymer is reported in the literature to be virtually inextractable into tributylphosphate (TBP) from $\mathrm{HNO}_{3}$ solutions and the extractability of Pu in leach solutions was cited earlier in these studies as evidence that polymer was not present in these solutions. It appears now that plutonium polymer can extract into TBP in the presence of fluoride. With polymer formed in dilute $\mathrm{HNO}_{3}(\mathrm{pH}=2.3)$, the distribution coefficient of $\mathrm{Pu}$ between $5 \underline{\mathrm{M}} \mathrm{HNO}_{3}-10^{-5} \underline{\mathrm{M}} \mathrm{Pu}$ and $30 \% \mathrm{TBP}-\mathrm{NPH}$ was 0.09 in the absence of added fluoride and 5 with $0.0025 \mathrm{M}$ fluoride added. The addition of aluminum ion to complex the fluoride did not prevent the extraction; in fact, the distribution coefficent increased to 7 when $0.015 \mathrm{M}$ Al was added along with $0.0025 \mathrm{M}$ fluoride.

A series of soil samples is being prepared by John Swanson for autoradiographic and possible electron microprobe examination. These soils are nonradioactive soils from cores drilled beside the 216-2-9 trench. They are to be reacted, or equilibrated, with plutonium of known forms under controlled conditions. For example, the first soil-plutonium equilibration was with plutonium polymer. An equilibration with plutonium hydroxide and other plutonium forms is planned. The soil samples will be plastic impregnated, polished and examined by autoradiographic techniques to determine plutonium polymer distribution, and to note any diagnostic differences between the occurrences of the different plutonium forms and their reactions with the soil. The plutonium polymer-soil sample is now being prepared for examination.

\section{6-Z-9 Covered Trench Soil Parameters}

(R. C. Routson and R. J. Serne, Water and Waste Management Section)

Work on an initial core sample from the 216-Z-9 covered trench was continued through the reporting period. Parameters which are being measured as a function of soil depth include 1) maximum infiltration rate in the absence of ponding, 2) $\mathrm{pH}$ in $0.01 \mathrm{M} \mathrm{CaCl}_{2}$, 3) porosity, 4) cation exchange capacity, 5) cadmium (Cd) content, 6) Cd sorption capacity, 7) moisture content, 8) $\mathrm{CaCO}_{3}$ content, and 9) plutonium (Pu) sorption. The soil was divided into eight subsamples as a function of depth and the above parameters 
were measured for each subsample. Subsamples were taken for the $0-1,1-3$, $3-6,6-9,9-12,12-15,15-18$, and 18-21 inch depths, respectively. Laboratory work on a11 of the above parameters was completed for the initial core sample.

\section{Tank Farm Support}

Partially Saturated Transient (PST) Flow Mode1 (A. E. Reisenauer and S. J. Phillips, Land Resources System Section)

Particle densities were measured on the soils from the T Tank Farm. Densities ranged from 2.8 to 2.9 , higher than expected.

A technique is being implemented to determine the hydraulic conductivity at one unsaturated point simultaneously with measuring moisture content on the gamma table. A cross check on the moisture in the system is being made by continuously recording the outflow fluid. These measurements will be used to improve the calculated hydraulic conductivities curves .

Improvements in the PST model are being checked prior to starting the $106 \mathrm{~T}$ Tank simulation.

Tests to establish reliability of the permeability calculating program FLOWTR are continuing. Several methods including analytic surfaces, computed steady state surfaces, and a transient surface generated from the VTT mode1 are being used to verify the program.

\section{Soil Waste Reactions}

(R. C. Routson and R. J. Serne, Water and Waste Management Section)

Work was continued to measure soil chemical and sorption parameters as a function of soil depth for a radionuclide transport model determination of the movement of radionuclides from a high-level waste tank leak. The laboratory work on the sorption parameters, ion exchange parameters, cation exchange capacity, $\mathrm{CaCO}_{3}$ content, and soluble ions in the soil for the first five soil samples has been completed. Laboratory work on the sorption parameters, cation exchange capacity, $\mathrm{CaCO}_{3}$ content, and soluble ions in the soil for a second group of two soil samples has also been completed. Work on the ion exchange parameters for the second group of soils is presently in progress. No soil samples from the "caliche" layer to the water table have been received as yet. 
Prevention of Accidental Releases

\section{- Surficial Contamination}

Instrumentation in Support of Environmental and Meteorological Surveillance (0. H. Koski, Chemical Development Section)

A review was made of methodology which may be used in the detection, data transmission and recording of alpha, beta, gamma and neutron emitting isotopes. The review will be used in selecting those methods and development areas most pertinent to current surveillance efforts.

B-C Crib Studies

(J. Mishima and L. C. Schwendinan, Particulate and Gaseous Waste Research Section)

Potential Airborne Release of Cs-137 Activity During a Range Fire in the B-C Controlled Area

Additional results have been received on the Cs-137 content of various types of materials collected from the surface of ten random $1 \mathrm{~m}^{2}$ plots. Measurement of the Cs-137 content is now complete. Surface concentrations of Cs-137 ranged from 0.53 to $55.9 \mu \mathrm{Ci} / \mathrm{m}^{2}$. Of that quantity, 10.3 percent was found in the flammable materials on the surface (vegetation, organic debris, animal droppings and sagebrush) and 89.7 percent in the soil to a depth of approximately $1 \mathrm{~cm}$. Soil, organic debris, and animal droppings were collected on all 10 plots. Live vegetation was found on 8 of 10 plots and sagebrush on half the plots. Considerable variation in Cs-137 concentration was found in all materials. Concentrations $(\mathrm{dpm} / \mathrm{g}$ ) found were as follows:

Vegetation. . .... from 22 to 510 ; avg. 120

Organic Debris. . . . . . from 120 to 1800; avg. 970

Animal Droppings. . . . . from 320 to $1.92 \times 10^{5}$; avg. $5.4 \times 10^{4}$

(A counting aliquot of $15.8 \mathrm{~g}$ from FSH 8 had a measured concentration of $5.0 \times 10^{5} \mathrm{dpm}$ per gram.)

Sagebrush . . . . . . f from 15 to 520; avg. 450

Soil (1 cm depth) . . . . from 47 to 2700 ; avg. 1300.

Although the average concentration in soil is low, the large mass contributed approximately 90 percent of the Cs-137 activity detected. Animal droppings ( 8 percent) and organic debris ( 1.5 percent) accounted for most of the remainder. 
Sieving of the less than $44 \mu \mathrm{m}$ soil fraction into 5 additional fractions greater than $37 \mu \mathrm{m}, 20$ to $37 \mu \mathrm{m}, 10$ to $20 \mu \mathrm{m}, 5$ to $10 \mu \mathrm{m}$ and 1 ess than $5 \mu \mathrm{m}$ was started using the sonic sifter.

Plans to sample other zones in the B-C Controlled Area to validate the initial distribution and to determine the $\mathrm{Sr}-90: \mathrm{Cs}-137$ ratio are being formulated.

\section{Fractional Releases from B-C Crib Area Materials}

The experimental program will be expanded to include releases of $\mathrm{Sr}-90$ and Cs-137 during heating to elevated temperatures and Sr-90 during burning of contaminated flammable materials. Fractional release data at higher wind speeds is desired and plans to appropriately modify the 242-B Wind Tunnel for these studies are being formulated. Study of the aerodynamic behavior of the solid residues will be carried out.

Potential Airborne Release of Activity During Planned Decontamination Operations -- Soil Removal Operations

(J. Mishima and L. C. Schwendiman, Particulate and Gaseous Waste Research Section)

Wind tunnel studies are planned to predict the fractional airborne release of Cs-137 (and by inference, Sr-90) during the digging and dumping of contaminated soil. Preliminary information on proposed apparatus for vacuum removal of surface contamination is being gathered to formulate experiments to evaluate the potential airborne release in the event of a collector bag rupture during operation.

Behavior of Radioactive Particles in a Soil Matrix (J. Mishima and L. C. Schwendiman, Particulate and Gaseous Waste Section)

An aliquot (624 g) of a uranium dioxide-soil mixture agitated in a cement mixer was sieved after mixing. The average calculated $\mathrm{UO}_{2}$ added was $0.084 \mathrm{~g} \mathrm{UO}_{2} / \mathrm{g}$ mixture compared to $0.088 \mathrm{~g} \mathrm{UO}_{2} / \mathrm{g}$ mixture measured. The $\mathrm{UO}_{2}$ concentration appeared to increase with decreasing particle size of the soil; i.e., $\mathrm{UO}_{2}$ concentrations in the two smallest size fractions used (74 to $44 \mu \mathrm{m}$ ) were 3.5 and 6 times higher than the nominal average concentration. The quantity of $\mathrm{UO}_{2}$ present in each fraction appeared to show some correlation to the assumed surface area of particles present in that fraction. The less-than $-44 \mu \mathrm{m}$ fraction is being classified further with a sonic sifter. Two aliquots of the mixture are being aged in shallow trays 
(with and without moisture) and a third in a 3 -inch diameter by 12 -inch cylinder to evaluate the influence of time and moisture on the distribution of radioactive particles in soil.

A portion of the coarse material $(0.42$ to $0.84 \mathrm{~mm})$ from Field Sample \#3 collected in the B-C Controlled Area, Zone 1 random sampling program was contacted with water to evaluate the effect of water on the activity present. Some material (organic) floated on the water. This was removed; the soil-water mixture was agitated and allowed to settle and the liquid portion was decanted through whatman 1 and membrane ( $3 \mu \mathrm{m}$ pore size) filters. Of the total activity present on the initial sample, about 2 percent was present on the floating material, $49.5 \%$ on the coarse soil and only $0.6 \%$ in the water. The floating material had an activity concentration of about $6 \times 10^{4} \mathrm{dpm} / \mathrm{g}$, the fine particles about $2 \times 10^{5} \mathrm{dpm} / \mathrm{g}$ and the coarse soil about $4 \times 10^{3} \mathrm{dpm} / \mathrm{g}$.

Particulate Resuspension Studies

G. A. Sehme1 and L. C. Schwendiman, Particulate and Gaseous waste Research Section)

One additional resuspension experiment at both U-Area and B-C Area was completed. Each 8 in. $x 10$ in. air filter from these experiments will be equilibrated to laboratory humidity before the filter is weighed and radioactive constituents measured. Rain shields were installed in the field to protect a11 8 in. $x 10$ in. filters from rain damage. Equipment installation for air sampling control by automatic wind instrumentation is continuing in the B-C Area. Radiochemistry analyses received from ARHCO this month for earlier experiments were converted to airborne radioactivity concentrations. Isotopes reported were $\mathrm{Cs}-137, \mathrm{Be}-7, \mathrm{Ru}-103$, and $\mathrm{Rh}-103$ with a11 airborne activity present well below MPC. Data are being processed to determine, if possible, the flux from the ground to air under the conditions which existed during these experiments.

Wind Trajectory Studies (R. K. Woodruff, L. L. Wende11, W. F. Sandusky and M. M. Orgi11, Atmospheric Sciences Department)

Trajectory calculations have been made using the wind data from the telemetry stations and supplementary stations set up for the two week experiment during the latter part of April. Constant volume balloon 
trajectories obtained during this period have been compared with the windfield-derived trajectories and found to be in reasonably good agreement for the few miles the balloons could be tracked by theodolite. The computer programs for analyzing the wind data from the wind network and performing trajectory calculations have been converted to run on the CDC 6600 computer. Plot programs for efficiently and economically displaying the windfields and trajectories are being added to present the data in a form that allows rapid but meaningful examination.

An attempt to get longer balloon tracks was investigated this month by following the balloon with the Battelle aircraft. Location and height readings were recorded by an observer in the aircraft. Ground observers also followed the balloon in a chase vehicle and recorded positions on a map. They could only estimate the balloon height but could simultaneously observe wind shear between the surface and balloon height. With an inexpensive range finder they could probably obtain a better estimate of the balloon height. Both methods show promise for trajectory determination during daylight hours. Although the aircraft provides more accuracy and can track much farther, a radar or a radiotheodolite would still have the advantage for night tracking.

The 400 foot tower winds were examined on several mornings with strong thermal stability. In 3 out of 4 observations the winds were light southerly in the lowest 100 foot but northwesterly about $10 \mathrm{mph}$ above the 100 foot leve1. This would suggest that the drainage flow from the slopes of the Rattlesnake hills to the south can be strong enough to overcome the general drainage flow from the northwest.

Further work will involve the analysis of wind and temperature data in locations where it is available at more than one leve1, i.e., the 400 foot Hanford tower, the 300 foot UNI tower at the 100-N Area, and the proposed 200 foot tower at the WPPSS No. 2 site. The purpose of this will be to determine the frequency of occurrence and the nature of vertical wind shear in the boundary layer of the Hanford site. This could provide some information on the validity of using the 20 foot telemetered winds to establish a transport climatology. More long balloon flights will be attempted for comparison with tower-derived trajectories and to provide more information on vertical windshear. 
- Groundwater Management Studies

Generation of an Improved Transmissivity Distribution

K. L. Kipp, Land Resources Systems Section)

The last two sets of water level measurements for the temporal rate of change map were made. The data is being entered into the computer for processing. Re-evaluation of the pre-1969 pump test data is still underway. Plans were drawn for new platforms for the water-1evel recorders recently obtained from ARHCO. A cost estimate is being prepared by the carpenter shop.

VTT Conversion to the CYBER

(W. V. DeMier, Computer Technology Section)

The numerical roundoff error of iterative processes is still under investigation by means of analytical test cases. This study will give a quantitative estimate of the rate of error growth as a function of the length of the simulation period and the number of time steps taken in that period. It will also lead to optimum convergency criteria limits for future simulations.

Development of a We11 Contamination Data Library (P. M. Schrotke, Land Resources Systems Section)

About two thirds of the gross beta contamination data has been put on computer cards. The tritium and nitrate data will also be assembled. This task is being done on a time available basis.

Field Measurements and Monitoring Assistance (K. L. Kipp, Land Resources Systems Section)

Preparations are being made to do a dye tracer study on the 216-U-10 pond, using visible light imaging scanner system. Two sets of measurements were made for moisture content of the soil in the lysimeters by means of the neutron probe on October 9 and 10 and again on October 24 and 25 .

Mode1 Development and Application

(S. W. AhIstrom and D. R. Friedrichs, Land Resources Systems Section)

The April 1973 water table contour map was redigitized with higher resolution for the PDP-9 travel time program. The matrix was examined with 
the Matrix Editor Program and errors were eliminated. As a result, many of the problems with streamline calculations were corrected.

- Biologica1 Transport Studies

Waterfow1 Census at Waste Ponds (J. D. Hedlund, Terrestrial Ecology Section)

The weekly waterfowl census was continued. A marked increase in pond lisage by waterfowl as well as small song birds was noted. The number of ducks, especially mallards and wigeons, has increased each sampling period. Thus far, no geese have been observed on the ponds. The usual large population of coots was still present on the Gable Mountain pond. The population of apparent resident species has remained relatively stable throughout the past few months.

Aquatic Studies at Gable Pond (D. G. Watson and C. E. Cushing, Fresh Water Ecology Section)

The two populations of experimental goldfish which have been enclosed over sediments and aquatic plants of relatively high and low levels of radioactivity have shown obvious differences in accumulation of body burdens of Cs-137. The fish were placed in the pond on May 25, 1973. Those in the area of higher levels of radioactivity are continuing to increase in levels of Cs-137 and had not stabilized as of August 30, 1973. At this time, they had roughly two times the body burden of $\mathrm{Cs}-137$ as did the fish held in the area of lower radioactivity. The latter fish attained apparent equilibrium by late July. Levels of $\mathrm{Zr}-95$ and Co-60 stabilized rapidly and at essentially the same concentration in both populations.

Analyses of core samples of the sediments, taken at the midpoint along five permanent transects, revealed that over 85 percent of the gamma radioactivity was in the upper 2 in. of sediments and that Cs-137 accounted for over 90 percent of the radioactivity.

Uptake of Actinide Elements by Plants Growing on Contaminated Soil (K. R. Price, Terrestrial Ecology Section)

These studies are directed toward understanding the assimilation of actinide elements by plants grown on soils contaminated with those elements. 
Root tissue analyses were completed for an experiment investiating the effects of placement depth on plant uptake. Neptunium-237, Pu-239, Am-241, and $\mathrm{cm}-244$ nitrate and oxalate solutions were added at mid-depth to pots containing $2 \mathrm{~kg}$ of soil. Roots were harvested separately from soil above and below the placement zone. In all cases except for $\mathrm{Np}$, uptake into root tissue above the placement zone was undetectable, whereas, in every case a considerable amount of radioactivity was detected in roots from below the zone. It appears unlikely that the transuranics leached through the soil from the placement zone and contaminated the root samples. An attempt will be made to verify this assumption.

Thus, it appears that $\mathrm{Np}, \mathrm{Pu}, \mathrm{Am}$, and $\mathrm{Cm}$ are translocated downward much more readily than upward within the plant body. The implication of these results to waste management is that some plants are capable of redistributing transuranic wastes downward from a radioactive layer in the soil. Upward movement, however, may be curtailed. Movement in plant root systems provides a mechanism whereby radioactivity can be spread within the soil, but the effect of such a spread on future plant uptake remains to be determined.

Soil used for plant uptake studies was recently determined to be low in sulfur, a nutrient essential for plant growth. The addition of ammonium sulfate fertilizer to tumbleweed and cheatgrass plants resulted in increased Pu-239 uptake from nitrate solutions added to soil. Uptake, expressed as concentration factors, was about 2.5 times greater with sulfate than without.

An interpretive error was uncovered concerning data from the experiment defining the effect of plant age on uptake of Pu-239 or Am-241 from dilute nitrate solutions added to soil. Uptake, expressed as concentration factors, decreases with time instead of increases as reported earlier. Trends of Np-237 and Am-241 uptake are similar to Pu-239 uptake in that concentration factors are very high for 2 week old plants and decrease rapidly as plants mature. Decreases level off at about 6 to 10 weeks. High concentration factors reflect high concentrations of activity per gram of plant material. Plants are young and succulent at this stage and are attractive to foraging animals. Animal consumption of radioactive plants at this stage would foster maximu plant-to-animal transfers. 


\section{$\underline{\text { Summary }}$}

Environmental Evaluations

Honey Hi11 Pond shows an increase in $\mathrm{Sr}-90$ contamination to $10 \mathrm{pCi} / \mathrm{l}$.

$\underline{\text { Radiation Protection }}$

Phase I of the computer program to automate the processing of in-vivo measurements was completed early in the month and is now being checked for any flaws that may exist in the logic.

Radiological Standards and Engineering

A new technique for making light covers on the alpha probes is being evaluated. Intercomparison standard chambers have been purchased to maintain traceability to the Nationa1 Bureau of Standards. A11 portable instruments were located for the witnessed inventory. 


\title{
TECHNICAL ASSISTANCE TO THE HANFORD PLANT
}

\author{
Environmental Evaluations \\ (J. P. Corley, Environmental Evaluations Section)
}

A routine Honey Hill Pond sample has shown a trend upward from the normal analytical results. The latest analysis indicates a total beta content of $280 \mathrm{pCi} / \ell$, a total alpha of $180 \mathrm{pCi} / \ell$ and a $\mathrm{Sr}-90$ of $10 \mathrm{pCi} / \ell$. Low water levels have interfered with normal sampling, at this location for several months, but special sampling is again in progress in an attempt to define the source of this radioactivity.

Routine monitoring for tritiated water vapor in the atmosphere was started this month in $\mathrm{N}$ Area using Linde Type $3 \mathrm{~A}$ molecular sieve material. The annual soil and vegetation sampling was completed and submitted to $U$. S. Testing. It will be several weeks before the results of the soil sampling are available.

All other measurements were within normal ranges, with the road monitoring indicating no detectable contamination on Hanford highways.

\section{Radiation Protection \\ (H. V. Larson, Personne1 Dosimetry Section)}

Phase one of the computer program to automate the processing of in-vivo measurements was completed early in the month and is now being checked by personnel at the Whole Body Counter to find any flaws that may exist in the logic. This phase consists of an interactive fortran computer program that is used to input identification and in-vivo examination data, perform some validity checking of the data and create an indexed sequential permanent disk file of the data to be used for subsequent processing. The programming of Phase two of this project is essentially complete; however, we are still encountering problems with the hardware that is creating the magnetic tape of the in-vivo count spectra. Phase three, the progranming for final processing of the in-vivo examination data, is proceeding on schedule. Preliminary report formats have been prepared to provide the contractors with a starting point in deciding their specific requirements for in-vivo count results and contacts with the contractors for their input have been initiated. 
The whole body counter recalibration was completed for the chair position, the mobile, the EDF shadow shield and the lung counter.

Extensive in-vivo examinations of two men who incurred a deposition of europium were begun. The design of the data acquisition for these two men is based on the development of a model to be used for subsequent incidences of europium inhalation.

\section{Radiation Standards and Engineering (J. M. Selby, Radiation Standards and Engineering)}

Another contractor proposed the use of a new ultra-thin aluminized Mylar for alpha probe light covers. The technique would include two layers of the thin material and no Dutch Leaf. The net result would be a 50 percent reduction in the density of the light cover. This technique had been successfully tried by the contractor with hand and shoe counters. The test with the alpha probes was unsatisfactory because of the increased number of light leaks. The rejection rate for new light covers is greater that 25 percent, thus, reliability in the field would not appear to be as high as with the old thicker Mylar plus Dutch Leaf. An alternate approach using two thin layers of Mylar plus one layer of Dutch Leaf is being tried. If this is not successful, the original technique will be continued.

Three intercomparison standard chambers have been received from Victoreen. The chambers cover the energy range of from $6.5 \mathrm{keV}$ to $1250 \mathrm{keV}$ and exposure rates up to $800 \mathrm{R} / \mathrm{min}$. Accuracy, as calibrated at Victoreen, is $\pm 3 \%$, and $\pm 2 \%$ when calibrated at the National Bureau of Standards. The chambers will be used as the primary reference for calibrations and periodically will be sent to NBS to maintain calibration.

The final two portable monitoring instruments have been located for this year's witnessed inventory. For the second year in a row all of the more than 1800 instruments were located. 
Meteorologica1 Services

(E. H. Phinney, Synoptic Meteorology Section)

Meteorological services, viz., weather forecasts and observations and climatological services were provided to plant operations and management on a routine basis.

\begin{tabular}{lccc} 
& No. Made & $\frac{0}{0}$ Reliability \\
Production Forecasts: & 93 & & 84.6 \\
General Forecasts: & 62 & & 88.0 \\
Special Forecasts: & 195 & 89.2 \\
Other Requests: & 285 & \\
Publications Distributed: & 140 & \\
Number of calls processed by Code-A-Phone & 4,459 & \\
\multicolumn{2}{l}{ TOTAL SERVICE ACTIONS } & 5,234
\end{tabular}




\section{DISTRIBUTION}

Copy

Number

$\underline{\text { OFF-SITE DISTRIBUTION }}$

1-3 USAEC, Washington-Division of Production

F. P. Baranowski

4-5 Technical Information Center, Oak Ridge, Tennessee

6 Savannah River AEC Operations Office

7-8 E. I. du Pont de Nemours \& Co.

Savannah River Laboratory

ON-SITE DISTRIBUTION

AEC Richland Operations Office

O. J. Elgert

R. L. Ferguson

P. G. Holsted

B. J. Melton

United Nuclear Industries, Inc.

P. A. Carlson

C. D. Corbit

R. E. Dunn

A. E. Engler

C. Harrington

R. T. Jessen

A. R. McGuire

N. R. Miller

J. T. Stringer/H. F. Tew

Atlantic Richfield Company

G. E. Backman

G. E. Benedict

G. L. Borsheim

D. J. Brown

L. E. Bruns

M. H. Campbe11

R. E. Fe1t

W. M. Harty

H. H. Hopkins

W. P. Ingalls

R. E. Isaacson

L. M. Knights

D. J. Larkin

W. D. Luening 


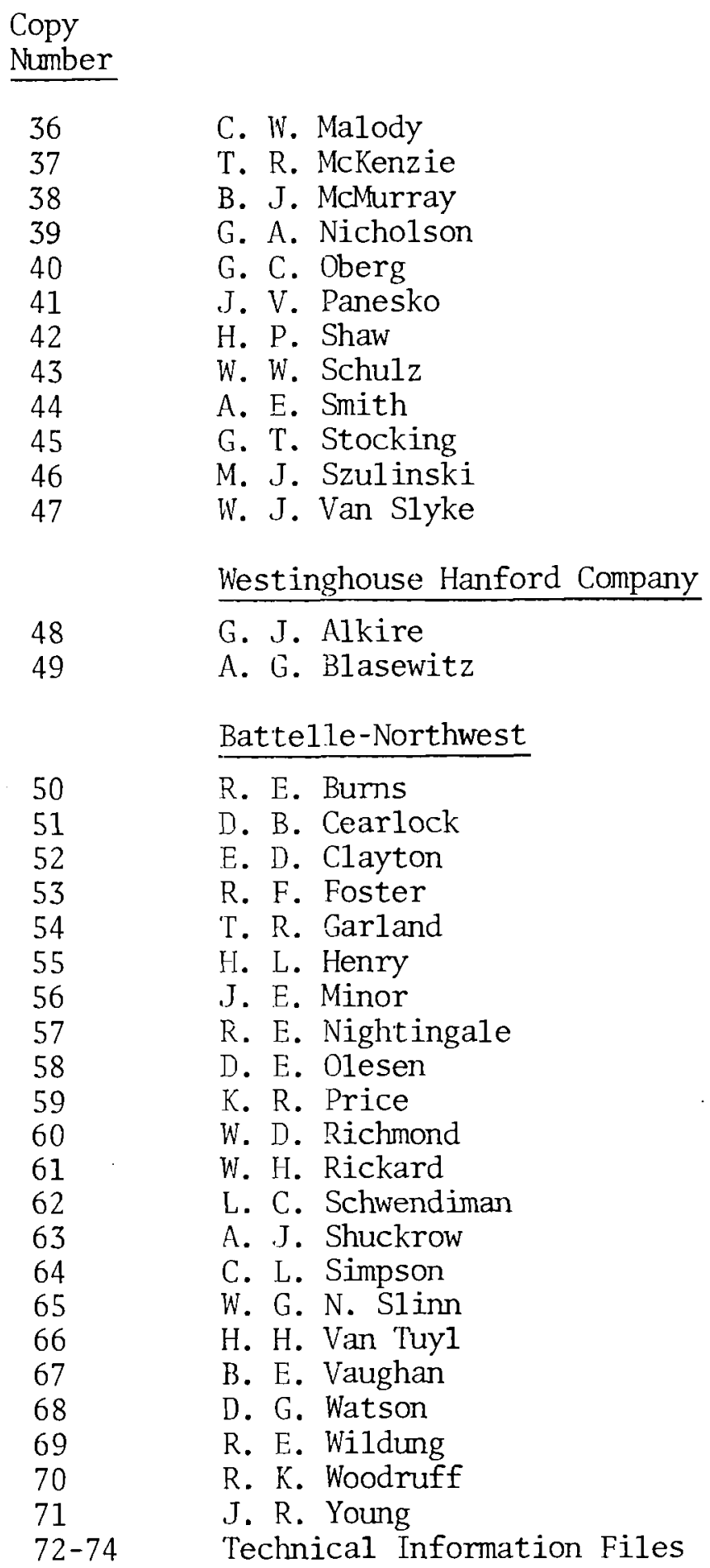

